\title{
On-Farm Pasteurized Milk Fed to Dairy Calves - Association of Bacteria Counts Following Pasteurization with Season, Temperature and Time until Feeding
}

\section{David J. Wilson*, Gregory M. Goodell and Tessa Kelly}

Department of Animal, Dairy and Veterinary Sciences, Utah State University, Logan, UT 84341 (Wilson), and the Dairy Authority, Greeley, CO 80634 , USA

\begin{abstract}
On-farm pasteurization of waste milk fed to calves has become increasingly common over the last 15 years This study investigated bacteria counts in milk before pasteurization and for $24 \mathrm{~h}$ following pasteurization at varying storage temperatures associated with seasons. Standard plate counts on Aerobic Count Plate Petrifilm ${ }^{\mathrm{TM}}$ to enumerate bacterial colony concentration were measured on raw and post-pasteurized milk after pasteurization at $63^{\circ} \mathrm{C}\left(145^{\circ} \mathrm{F}\right)$ for 30 min using commercial pasteurizers on 3 different commercial dairy farms. Each farm was sampled in each of 4 seasons of the year. All 12 batches of milk were divided into 2 aliquots. One aliquot was incubated at controlled temperature to mimic the season (refrigerated, room temperature, or incubated at $37^{\circ} \mathrm{C}$ ) and the other was incubated at ambient outdoor temperatures. The SPC was determined at pre-pasteurization, 0 (immediately post-pasteurization), 1, 2, 3, 4, 5, 6, 7, 8, 10, 12 and $24 \mathrm{~h}$ post-pasteurization. The final general linear model testing for factors associated with LogSPC was highly explanatory $\left(R^{2}=0.71\right)$, and significant $(P<0.0001)$. This final model for LogSPC included time since pasteurization, season, farm, the interaction of time and season, and the interaction of season and farm. The model showed that passage of time was associated with increased LogSPC, especially during summer. In a northern temperate climate under the conditions observed during this study, milk could safely be fed-if defined as SPC $<20,000 \mathrm{cfu} / \mathrm{ml}$-for at least $8 \mathrm{~h}$ post-pasteurization during fall and spring, and for $24 \mathrm{~h}$ during winter, but only for $3 \mathrm{~h}$ if milk was stored outside during the summer. These results suggest that for milk kept outdoors during summer, any milk remaining after first feeding following pasteurization should not be fed to calves at subsequent feedings, but instead should be re-pasteurized or discarded.
\end{abstract}

Keywords: Pasteurization; Milk; Bacteria Count; Calves

\section{Introduction}

On-farm pasteurization of waste milk fed to calves has become increasingly common over the last 15 years [1-4], and has also been demonstrated to be profitable and of benefit to calf health $[2,3]$. However, there is inconsistency in bacterial reduction in pasteurized milk on dairy farms, due to mechanical and performance differences among farms. Bacteria counts are often greatly reduced from the levels in raw milk, but can rapidly recover and even increase to greater levels than those in raw milk even after few hours $[2,3,5]$.

Pasteurized milk is often stored at ambient temperature for 4 to $8 \mathrm{~h}$ or more on farms before it is fed. The primary reason for this is that when an afternoon or night milking is completed, discard milk, such as from treated or recently calved cows is usually pasteurized soon afterward. However, the next feeding time for the dairy calves is often many hours later. Dairy producers do not usually wait to pasteurize milk because pasteurization can usually be started by some farm personnel while others clean the milking parlor, and the milk has to cool before it can be handled and then subsequently fed to calves.

There is a need for standardization of recommendations for specific pasteurization procedures and subsequent feeding of milk to calves on dairy farms [5]. There are no published studies regarding the effects of time until feeding of pasteurized milk on bacterial numbers in the milk, or the effects of variations in storage temperatures on the increase in bacteria before the milk is fed. This study investigated bacteria counts in raw milk, immediately post-pasteurized milk, and milk at time intervals up to $24 \mathrm{hr}$ following pasteurization at varying storage temperatures. The principal objectives were to evaluate the change in milk bacteria counts as time passed following pasteurization and to investigate potential differences in how bacteria counts increased over time between seasons and their associated ranges of ambient temperature.

Some suggested standards state that only milk with bacteria counts less than $20,000 \mathrm{cfu} / \mathrm{ml}$ should be fed to calves, although associations with health effects on calves have not been studied [5]. Therefore a secondary objective was to evaluate the time following pasteurization that passed before bacteria counts increased to levels greater than $20,000 \mathrm{cfu} / \mathrm{ml}$, including potential time differences between seasons and their associated ranges of ambient temperature.

\section{Materials and Methods}

\section{Study herds}

Three commercial dairy farms in Colorado milking approximately 800, 2400 and 1800 Holstein cows participated in the study (Farms A, $\mathrm{B}$, and $\mathrm{C})$. Commercially made batch pasteurizers were used within old bulk milk tanks to pasteurize discard milk at $63^{\circ} \mathrm{C}\left(145^{\circ} \mathrm{F}\right)$ for 30

*Corresponding author: David J. Wilson, Department of Animal, Dairy and Veterinary Sciences, Utah State University, Utah Veterinary Diagnostic Laboratory, 950 East 1400 North, Logan, UT 84341, USA, Tel: 435-760-3731; Fax: 435-7972805; E-mail: David.Wilson@usu.edu

Received August 03, 2012; Accepted October 20, 2012; Published October 22 2012

Citation: Wilson DJ, Goodell GM, Kelly T (2012) On-Farm Pasteurized Milk Fed to Dairy Calves - Association of Bacteria Counts Following Pasteurization with Season, Temperature and Time until Feeding. J Vet Sci Technol 3:124 doi:10.4172/2157-7579.1000124

Copyright: @ 2012 Wilson DJ, et al. This is an open-access article distributed unde the terms of the Creative Commons Attribution License, which permits unrestricted use, distribution, and reproduction in any medium, provided the original author and source are credited. 
Citation: Wilson DJ, Goodell GM, Kelly T (2012) On-Farm Pasteurized Milk Fed to Dairy Calves - Association of Bacteria Counts Following Pasteurization with Season, Temperature and Time until Feeding. J Vet Sci Technol 3:124 doi:10.4172/2157-7579.1000124

Page 2 of 5

min, and the milk was later fed to replacement heifer calves. Cows that had recently calved or were treated with antibiotics were milked into the pasteurizer tanks, and pasteurization was begun after each such milking ended. There was no change made during the study to the pasteurization methods already employed on the farms.

\section{Milk collection and handling}

One batch of milk was collected from each of the 3 study farms during each of the following 4 seasons: summer (June 21-Sept. 20), fall (Sept. 21-Dec. 20), winter (Dec. 21-March 20), and spring (March 21June 20). During the milking of cows whose milk was discarded, the milk was periodically agitated in the pasteurizer tank but not cooled. The pre-pasteurized milk sample from each batch was aseptically collected into an $11 \mathrm{ml}$ sterile vial by farm personnel just before the raw discard milk was pasteurized, following agitation of the milk, and immediately placed in a refrigerator on the farm at approximately $4^{\circ} \mathrm{C}$. Personnel from The Dairy Authority (TDA) in Greeley, CO arrived on the farm shortly before pasteurization ended. After pasteurization, as soon as milk cooled to $49^{\circ} \mathrm{C}\left(120^{\circ} \mathrm{F}\right)$, they aseptically collected one milk sample -at $0 \mathrm{~h}$, representing the time at which pasteurization ended and milk was cooled enough to be handled - into an $11 \mathrm{ml}$ sterile vial. Personnel from TDA also inoculated all pre-pasteurization milk samples (that had been refrigerated by farm personnel) and all $0 \mathrm{~h}$ milk samples onto Petrifilm ${ }^{\mathrm{TM}}$ (Aerobic Count Plate, 3M Microbiology, St. Paul, MN) before leaving the farm. Microbiological methods will be described further. The inoculated films were placed into a portable incubator at $37^{\circ} \mathrm{C}$. Next each batch of milk was divided into 2 aliquots of $6 \mathrm{~L}$ each by study personnel; these $6 \mathrm{~L}$ aliquots were transported at ambient temperature until arrival at the laboratory. All milk samples were transported to the laboratory of TDA within approximately 30 min, where the rest of the microbiological procedures were done.

One aliquot of each batch of milk was incubated indoors at TDA as follows: Fall (Sept. 21-Dec. 20), room temperature (target temperature $22^{\circ} \mathrm{C}$ ); Winter (Dec. 21-March 20), refrigerated (target temperature $4^{\circ} \mathrm{C}$ ); Spring (March 21-June 20), room temperature (target temperature $22^{\circ} \mathrm{C}$ ); Summer (June 21-Sept. 20), incubated (target temperature $37^{\circ} \mathrm{C}$ ). The other aliquot of each batch of milk was incubated outdoors at TDA in a plastic tub with a clear top with a thermometer placed in the milk and therefore exposed to seasonal ambient temperature. Subsequent milk samples were aseptically collected at 1, 2, 3, 4, 5, 6, 7, 8 , and $24 \mathrm{~h}$ post-pasteurization. Temperature was recorded at each time point when milk was sampled. For some batches, additional samples were collected at 10 and $12 \mathrm{~h}$ post-pasteurization.

\section{Bacteria counts}

Bacterial concentrations in milk samples were enumerated using Aerobic Count Plate Petrifilm to determine SPC according to Standard Methods [6]. Each milk sample ( $1 \mathrm{ml}$ inoculum) was pipetted onto Petrifilm at different dilutions - this had also been done with the pre-pasteurization and $0 \mathrm{~h}$ samples inoculated on the farm as described earlier - in Butterfield's Buffer (3M Microbiology, St. Paul, $\mathrm{MN}$ ) according to logical expectations of the range of bacteria counts expected: pre-pasteurized samples - undiluted, $10^{-2}, 10^{-3}, 10^{-4}, 10^{-5}, 10^{-6}$; 0 to $12 \mathrm{~h}$ post-pasteurization - undiluted, $10^{-1}, 10^{-2}, 10^{-3}, 10^{-4} ; 24 \mathrm{~h}$ postpasteurization - undiluted, $10^{-1}, 10^{-2}, 10^{-3}, 10^{-4}, 10^{-5}, 10^{-6}$. However, during the summer, as SPC were increasing to higher levels, as time progressed since pasteurization, subsequent dilutions of up to $10^{-10}$ were made. There were no samples where the highest dilution resulted in colonies too numerous to count.

\section{Statistical analysis}

Systat 13 was used for statistical testing. The SPC were transformed to the $\log$ of SPC ( $\log S P C)$ for analyses, and then reverse-transformed to raw SPC for some descriptive statistics. Analysis of variance (ANOVA), and if significant differences were indicated, Tukey's multiple comparison test were used to evaluate differences in means of continuous variables (LogSPC, temperature) among categorical variables (Season, Farm, indoor or outdoor incubation) at each different time relative to pasteurization. General linear models (GLM) evaluated the association of potential explanatory variables with the continuous outcome variable of interest, LogSPC. The initial general linear model (PROC GLM) testing for factors associated with LogSPC was:

$\mathrm{Y}=$ Time + Season+Farm + Incubation + Time $\times$ Season + Time $\times F a$ $\mathrm{rm}+$ Time $\times$ Incubation + Season $\times$ Farm + Season $\times$ Incubation + Farm $\times$ Incubation + Time $\times$ Season $\times$ Farm + Season $\times$ Farm $\times$ Incubation + Time $\times$ Season $\times$ Farm $\times$ Incubation $+e$

Where $\mathrm{Y}=\mathrm{LogSPC}$; Time $=\mathrm{hr}$ relative to pasteurization (where $0=$ immediately post-pasteurization, 1 to $24 \mathrm{hr}=$ post-pasteurization); Season=Fall, Winter, Spring or Summer; Farm=farm A, B or C; Incubation=Indoor or Outdoor; Time $\times$ Season, etc.=interaction terms, whether one factors' effect on $\mathrm{Y}$ is associated with another factor e.g. whether LogSPC increases faster during Summer than during other seasons, and $e=$ unexplained variation.

Non-significant variables were sequentially removed until all significantly associated explanatory variables remained in a final model. Level of statistical significance used was $\alpha=0.05$.

\section{Results}

The mean, median and range of incubation temperatures for the post-pasteurized milk samples during the seasons were as follows: Fall, indoor $(\mathrm{n}=27) 23^{\circ} \mathrm{C}, 23^{\circ} \mathrm{C},\left(21\right.$ to $\left.26^{\circ} \mathrm{C}\right)$, ambient outdoors $(\mathrm{n}=27) 8^{\circ} \mathrm{C}$, $8^{\circ} \mathrm{C}\left(-5\right.$ to $\left.17^{\circ} \mathrm{C}\right)$; Winter, indoor refrigerated $(\mathrm{n}=33) 6^{\circ} \mathrm{C}, 6^{\circ} \mathrm{C}(2$ to $\left.10^{\circ} \mathrm{C}\right)$, ambient outdoors $(\mathrm{n}=33) 8^{\circ} \mathrm{C}, 9^{\circ} \mathrm{C}\left(-5\right.$ to $\left.25^{\circ} \mathrm{C}\right)$; Spring, indoor $(\mathrm{n}=33) 18^{\circ} \mathrm{C}, 17^{\circ} \mathrm{C}\left(14\right.$ to $\left.19^{\circ} \mathrm{C}\right)$, ambient outdoors $(\mathrm{n}=33) 10^{\circ} \mathrm{C}, 9^{\circ} \mathrm{C}$ ( 5 to $25^{\circ} \mathrm{C}$ ); Summer, indoor in incubator $(\mathrm{n}=33) 37^{\circ} \mathrm{C}, 37^{\circ} \mathrm{C}(35$ to $\left.39^{\circ} \mathrm{C}\right)$, ambient outdoors $(\mathrm{n}=33) 30^{\circ} \mathrm{C}, 28^{\circ} \mathrm{C}\left(18\right.$ to $\left.43^{\circ} \mathrm{C}\right)$. The mean indoor (room temperature during Fall and Spring, refrigerated during Winter, incubated during Summer) temperatures were all significantly different among the 4 seasons $(\mathrm{P}<0.0001$, ANOVA, Tukey's). The mean ambient outdoor temperatures were not significantly different during Fall, Winter or Spring, but Summer had significantly higher outdoor temperatures (mean $\left.30^{\circ} \mathrm{C}\right)$ than each of the other 3 seasons $(\mathrm{P}<0.0001$, ANOVA, Tukey's, Tables 3-6).

The LogSPC (in $\mathrm{cfu} / \mathrm{ml})$ ( $\mathrm{n}=12 ; 3$ farms, 4 seasons) immediately before pasteurization were compared by farm and season; there were no significant differences in pre-pasteurized LogSPC between farms $(\mathrm{P}=0.99$, ANOVA $)$ or seasons $(\mathrm{P}=0.12$, ANOVA). The mean prepasteurized LogSPC during the 4 seasons were as follows: Fall 7.8, Winter 12.7, Spring 14.4, and Summer 12.6.

The change in $\operatorname{LogSPC}$ ( $\mathrm{n}=24 ; 3$ farms, 2 time points, 4 seasons) from pre-pasteurization $(-1 \mathrm{hr})$ to post-pasteurization $(0 \mathrm{hr})$ was analyzed. Mean LogSPC decreased significantly after pasteurization $(\mathrm{P}<0.0001$, ANOVA). The most significant decreases in (reverse transformed) raw SPC following pasteurization were during Winter from $439,000 \mathrm{cfu} / \mathrm{ml}$ to $809 \mathrm{cfu} / \mathrm{ml}$ (Table 4) and during Spring from 1,749,167 cfu/ml to $1194 \mathrm{cfu} / \mathrm{ml}$ (Table 5) $(\mathrm{P}<0.05$, Tukey's).

The final GLM to test for factors associated with $\operatorname{LogSPC}(n=285)$ 
Citation: Wilson DJ, Goodell GM, Kelly T (2012) On-Farm Pasteurized Milk Fed to Dairy Calves - Association of Bacteria Counts Following Pasteurization with Season, Temperature and Time until Feeding. J Vet Sci Technol 3:124 doi:10.4172/2157-7579.1000124

Table 1: General linear model estimated effects of significant factors on log of bacteria count (LogSPC in cfu/ml) in milk following pasteurization.

\begin{tabular}{|c|c|}
\hline Parameter & Estimated Effect§ \\
\hline Intercept & 5.82 \\
\hline Time $¥$ & 0.13 \\
\hline Fall $†$ & -2.95 \\
\hline Summer & 2.83 \\
\hline Farm A $\ddagger$ & -0.54 \\
\hline Time*Summer£ & 0.24 \\
\hline Farm B*Spring€ & 1.39 \\
\hline Farm A*Summer & 1.15 \\
\hline
\end{tabular}

$\S$ Estimated effect on log of SPC bacteria count (log of cfu/ml) in milk

$¥$ Effect of each increase in $1 \mathrm{hr}$ of time since pasteurization

$\dagger$ Effect of season (Winter is baseline season)

$\ddagger$ Effect of farm (Farm $C$ is baseline farm)

$£$ Interaction - Effect of each increase in $1 \mathrm{hr}$ of time since pasteurization during each season; SPC increased more with each $\mathrm{hr}$ since pasteurization during Summer (Winter is baseline)

$€$ Interaction - effect of season on a specific farm (Farm $C$ is baseline farm) $\mathrm{R}^{2}=0.71, \mathrm{P}<0.0001$

Table 2: General linear model tests of significance for effects on log of bacteria count (LogSPC in cfu/ml) in milk following pasteurization (see Table 1 for explanation of Time, Season and Farm).

\begin{tabular}{|c|c|c|c|c|c|}
\hline Source & Type III SS & $\begin{array}{c}\text { degrees of } \\
\text { freedom }\end{array}$ & $\begin{array}{c}\text { Mean } \\
\text { Squares }\end{array}$ & F-ratio & P-value \\
\hline Time & 203.53 & 1 & 203.53 & 39.0 & $<0.0001$ \\
\hline Season & 586.81 & 3 & 195.60 & 37.5 & $<0.0001$ \\
\hline Farm & 65.43 & 2 & 32.72 & 6.3 & 0.002 \\
\hline Time*Season£ & 303.67 & 3 & 101.22 & 19.4 & $<0.0001$ \\
\hline Season*Farm€ & 524.50 & 6 & 87.42 & 16.7 & $<0.0001$ \\
\hline Error & 1410.24 & 270 & 5.22 & & \\
\hline
\end{tabular}

$£$ Interaction - effect of each increase in $1 \mathrm{hr}$ of time since pasteurization within each season; see Table 1 for estimated effects

$€$ Interaction - effect of season on a specific farm; see Table 1 for estimated effects $R^{2}=0.71, P<0.0001$

was highly explanatory for variation in $\operatorname{LogSPC}\left(\mathrm{R}^{2}=0.71\right)$, and highly significant $(\mathrm{P}<0.0001)$. This final GLM for LogSPC included Time since pasteurization, Season, Farm, the interaction of Time and Season, and the interaction of Season and Farm. The model showed that passage of Time was associated with increased LogSPC, especially during Summer, that Summer alone was associated with higher log of bacteria count, and that these effects were especially observed on Farm A. Also, Spring was associated with relatively higher log of bacteria count on Farm B than on other farms, despite the overall highest increase in LogSPC during Summer (Tables 1 and 2). Incubation, whether aliquots of samples were incubated indoors or outdoors, was not significantly associated with LogSPC.

The changes in raw SPC after pasteurization during each season are shown in Tables 3-6. In Fall, for the samples incubated indoors (at room temperatures centered around $23^{\circ} \mathrm{C}$ ), SPC (mean of 3 farms) did not increase above $20,000 \mathrm{cfu} / \mathrm{ml}$ until after the $8 \mathrm{~h}$ sample $(7,796 \mathrm{cfu} /$ $\mathrm{ml})$, increasing to $2,121,818 \mathrm{cfu} / \mathrm{ml}$ with a median of $206,364 \mathrm{cfu} / \mathrm{ml}$ by the time of the next sample at $24 \mathrm{~h}$. The Fall outdoor samples were incubated at ambient temperatures centered around $8^{\circ} \mathrm{C}$ and never had SPC greater than $37 \mathrm{cfu} / \mathrm{ml}$ for $24 \mathrm{~h}$ (Table 3).

In Winter, all samples both refrigerated indoors and incubated outdoors were at cool temperatures (centered around $7^{\circ} \mathrm{C}$ ). After a mean raw SPC of $809 \mathrm{cfu} / \mathrm{ml} 1 \mathrm{hr}$ post-pasteurization, no subsequent SPC were greater than $228 \mathrm{cfu} / \mathrm{ml}$ for $24 \mathrm{~h}$ (Table 4).

In Spring, for the samples incubated indoors (at room temperatures
Table 3: Standard plate counts for bacteria in pasteurized milk samples over time post pasteurization by incubation method and hourly temperature for Fall season. Each value is the mean for 3 samples, one from each study farm.

\begin{tabular}{|c|c|c|c|}
\hline $\begin{array}{l}\text { Time }(\mathrm{h}) \text { relative to } \\
\text { pasteurization }\end{array}$ & $\begin{array}{l}\text { Standard Plate Count } \\
(\mathrm{cfu} / \mathrm{ml})\end{array}$ & Incubation & $\begin{array}{c}\text { Temperature } \\
\left({ }^{\circ} \mathrm{C}\right)\end{array}$ \\
\hline$-1 \S$ & 6861 & Farm & NR \\
\hline $0 £$ & 40 & Farm & 13 \\
\hline 1 & 59 & Indoor¥ & 24 \\
\hline 2 & 25 & Indoor & 24 \\
\hline 3 & 23 & Indoor & 24 \\
\hline 4 & 30 & Indoor & 23 \\
\hline 5 & 38 & Indoor & 23 \\
\hline 6 & 91 & Indoor & 23 \\
\hline 7 & 6068 & Indoor & 23 \\
\hline 8 & 7796 & Indoor & 23 \\
\hline 24 & $2,121,818 \dagger$ & Indoor & 22 \\
\hline 1 & 28 & Outdoor & 5 \\
\hline 2 & 20 & Outdoor & 6 \\
\hline 3 & 24 & Outdoor & 8 \\
\hline 4 & 35 & Outdoor & 9 \\
\hline 5 & 32 & Outdoor & 9 \\
\hline 6 & 31 & Outdoor & 11 \\
\hline 7 & 29 & Outdoor & 11 \\
\hline 8 & 37 & Outdoor & 11 \\
\hline 24 & 25 & Outdoor & 1 \\
\hline
\end{tabular}

\$-1 indicates immediately pre-pasteurization; raw milk on the farm

$£ 0$ indicates immediately post-pasteurization

NR=Not recorded

$¥$-Indoor incubation was at room temperature during Fall

†-Median=206,364 cfu/ml

Table 4: Standard plate counts for bacteria in pasteurized milk samples over time post-pasteurization by incubation method and hourly temperature for Winter season. Each value is the mean for 3 samples, one from each study farm.

\begin{tabular}{|c|c|c|c|}
\hline $\begin{array}{l}\text { Time }(\mathrm{h}) \text { relative to } \\
\text { pasteurization }\end{array}$ & $\begin{array}{c}\text { Standard Plate Count } \\
\text { (cfu/ml) }\end{array}$ & Incubation & $\begin{array}{c}\text { Temperature } \\
\left({ }^{\circ} \mathrm{C}\right)\end{array}$ \\
\hline$-1 \S$ & 439,000 & Farm & 8 \\
\hline $0 £$ & 809 & Farm & 43 \\
\hline 1 & 103 & Indoor $¥$ & 7 \\
\hline 2 & 123 & Indoor & 6 \\
\hline 3 & 137 & Indoor & 6 \\
\hline 4 & 163 & Indoor & 6 \\
\hline 5 & 157 & Indoor & 6 \\
\hline 6 & 172 & Indoor & 5 \\
\hline 7 & 185 & Indoor & 5 \\
\hline 8 & 177 & Indoor & 5 \\
\hline 10 & 181 & Indoor & 5 \\
\hline 12 & 163 & Indoor & 5 \\
\hline 24 & 173 & Indoor & 5 \\
\hline 1 & 150 & Outdoor & 2 \\
\hline 2 & 121 & Outdoor & 5 \\
\hline 3 & 132 & Outdoor & 7 \\
\hline 4 & 147 & Outdoor & 9 \\
\hline 5 & 173 & Outdoor & 10 \\
\hline 6 & 180 & Outdoor & 13 \\
\hline 7 & 168 & Outdoor & 14 \\
\hline 8 & 150 & Outdoor & 13 \\
\hline 10 & 163 & Outdoor & 13 \\
\hline 12 & 228 & Outdoor & 7 \\
\hline 24 & 148 & Outdoor & 2 \\
\hline
\end{tabular}

$\S-1$ indicates immediately pre-pasteurization; raw milk on the farm $£ 0$ indicates immediately post-pasteurization $¥$ Indoor incubation was refrigeration during Winter 
Citation: Wilson DJ, Goodell GM, Kelly T (2012) On-Farm Pasteurized Milk Fed to Dairy Calves - Association of Bacteria Counts Following Pasteurization with Season, Temperature and Time until Feeding. J Vet Sci Technol 3:124 doi:10.4172/2157-7579.1000124

Table 5: Standard plate counts for bacteria in pasteurized milk samples over time post-pasteurization by incubation method and hourly temperature for Spring season. Each value is the mean for 3 samples, one from each study farm.

\begin{tabular}{|c|c|c|c|}
\hline $\begin{array}{l}\text { Time }(\mathrm{hr}) \text { relative to } \\
\text { pasteurization }\end{array}$ & $\begin{array}{l}\text { Standard Plate Count } \\
\text { (cfu/ml) }\end{array}$ & Incubation & $\begin{array}{c}\text { Temperature } \\
\left({ }^{\circ} \mathrm{C}\right)\end{array}$ \\
\hline$-1 \S$ & $1,749,167$ & Farm & NR \\
\hline $0 £$ & 1194 & Farm & 48 \\
\hline 1 & 1323 & Indoor¥ & 17 \\
\hline 2 & 1780 & Indoor & 18 \\
\hline 3 & 1434 & Indoor & 18 \\
\hline 4 & 1747 & Indoor & 18 \\
\hline 5 & 1609 & Indoor & 18 \\
\hline 6 & 1340 & Indoor & 17 \\
\hline 7 & 1854 & Indoor & 17 \\
\hline 8 & 1210 & Indoor & 17 \\
\hline 10 & 1699 & Indoor & 17 \\
\hline 12 & 1904 & Indoor & 17 \\
\hline 24 & $9,234,633$ & Indoor & 18 \\
\hline 1 & 1349 & Outdoor & 7 \\
\hline 2 & 1353 & Outdoor & 7 \\
\hline 3 & 1435 & Outdoor & 11 \\
\hline 4 & 1212 & Outdoor & 12 \\
\hline 5 & 1405 & Outdoor & 10 \\
\hline 6 & 1291 & Outdoor & 10 \\
\hline 7 & 1255 & Outdoor & 10 \\
\hline 8 & 1096 & Outdoor & 10 \\
\hline 10 & 1127 & Outdoor & 15 \\
\hline 12 & 1299 & Outdoor & 10 \\
\hline 24 & 992 & Outdoor & 8 \\
\hline
\end{tabular}

$\S-1$ indicates immediately pre-pasteurization; raw milk on the farm $£ 0$ indicates immediately post-pasteurization

$\mathrm{NR}=$ Not recorded

$¥$-Indoor incubation was at room temperature during Spring

centered around $18^{\circ} \mathrm{C}$ ), raw SPC mean did not increase above 20,000 $\mathrm{cfu} / \mathrm{ml}$ until after the $12 \mathrm{~h}$ sample $(1,904 \mathrm{cfu} / \mathrm{ml})$, increasing to $9,234,633 \mathrm{cfu} / \mathrm{ml}$ with a median of $8,900,000 \mathrm{cfu} / \mathrm{ml}$ by the time of the next sample at $24 \mathrm{~h}$. The Spring outdoor samples were incubated at ambient temperatures centered around $10^{\circ} \mathrm{C}$ and never had SPC greater than $1435 \mathrm{cfu} / \mathrm{ml}$ for $24 \mathrm{~h}$ (Table 5).

In Summer, for samples incubated indoors (at temperatures centered around $37^{\circ} \mathrm{C}$ ), raw SPC was greater than $20,000 \mathrm{cfu} / \mathrm{ml}$ by 4 $\mathrm{hr}(186,800 \mathrm{cfu} / \mathrm{ml})$ and increased markedly after that, reaching a mean of $200,005,443,333 \mathrm{cfu} / \mathrm{ml}$ and median of $14,500,000 \mathrm{cfu} / \mathrm{ml}$ by $24 \mathrm{hr}$. Outdoor samples were incubated at ambient temperatures centered around $30^{\circ} \mathrm{C}$. Standard plate count was greater than $20,000 \mathrm{cfu} / \mathrm{ml}$ by 3 $\mathrm{hr}(34,200 \mathrm{cfu} / \mathrm{ml})$ and increased markedly after that, reaching a mean of $66,075,516,061 \mathrm{cfu} / \mathrm{ml}$ with a median of $44,000,000 \mathrm{cfu} / \mathrm{ml}$ by $24 \mathrm{hr}$ (Table 6).

\section{Discussion}

While pasteurized milk is increasingly fed to calves on dairy farms or dairy heifer raising operations, there is currently no agreement upon "safety threshold" for bacteria counts above which milk should not be fed to calves [5]. Others have speculated that this number is between 20,000 and $100,000 \mathrm{cfu} / \mathrm{ml}$, with no published direct evidence regarding health effects on calves. Some recommendations have been made previously that only milk with bacteria counts less than $20,000 \mathrm{cfu} / \mathrm{ml}$ should be fed to calves, but it was observed that less than $2 \%$ of farms could meet this goal [5]. A primary reason for the suggested limit of $20,000 \mathrm{cfu} / \mathrm{ml}$ of bacteria in calf milk is extrapolation from the United
States Pasteurized Milk Ordinance which states that it is the upper limit for safety of milk consumed by humans [7]. Another recent study reported that of 147 batches of pasteurized milk intended for feeding to calves on 6 dairy farms, $21 \%$ of the batches had SPC $>20,000 \mathrm{cfu} / \mathrm{ml}$ after pasteurization [1]

Under conditions of the study reported here (except on days with unseasonably warm temperatures, which did not occur during the study period), milk could have been safely fed to calves - SPC $<20,000$ $\mathrm{cfu} / \mathrm{ml}$-during fall for at least $8 \mathrm{hr}$ post-pasteurization, during spring for at least $12 \mathrm{~h}$, and during winter for at least $24 \mathrm{hr}$. During summer, it was important whether pasteurized milk was stored outside, as is common on farms, or whether it could be stored completely indoors at room temperature between 18 and $23^{\circ} \mathrm{C}$ (or cooler). During summer, outdoor temperatures as would be expected in a northern temperate climate were markedly and statistically significantly higher than for the other seasons, and so was the growth of bacteria as time passed following pasteurization. Thus, in summer, milk stored outdoors could have been safely fed as defined by SPC $<20,000 \mathrm{cfu} / \mathrm{ml}$ for only $3 \mathrm{~h}$ post-pasteurization, and by $4 \mathrm{~h}$, feeding it would definitely not have been recommended. On most dairy farms, some milkings produce more discard milk than can be fed to calves at the next feeding, and therefore some milk is left over. Especially during summer, or in warm climates where temperatures exceed $30^{\circ} \mathrm{C}$ during other seasons of the

Table 6: Standard plate counts for bacteria in pasteurized milk samples over time post-pasteurization by incubation method and hourly temperature for Summer season. Each value is the mean for 3 samples, one from each study farm.

\begin{tabular}{|c|c|c|c|}
\hline $\begin{array}{l}\text { Time }(\mathrm{h}) \text { relative to } \\
\text { pasteurization }\end{array}$ & $\begin{array}{l}\text { Standard Plate Count } \\
\text { (cfu/ml) }\end{array}$ & Incubation & $\begin{array}{c}\text { Temperature } \\
\left({ }^{\circ} \mathrm{C}\right)\end{array}$ \\
\hline$-1 \S$ & $56,342,000$ & Farm & NR \\
\hline $0 £$ & 8489 & Farm & 37 \\
\hline 1 & 2370 & Indoor $¥$ & 37 \\
\hline 2 & 17,747 & Indoor & 37 \\
\hline 3 & 17,140 & Indoor & 36 \\
\hline 4 & 186,800 & Indoor & 36 \\
\hline 5 & $1,054,900 \dagger$ & Indoor & 36 \\
\hline 6 & $1,739,333$ & Indoor & 36 \\
\hline 7 & $6,498,309 \ddagger$ & Indoor & 37 \\
\hline 8 & $43,400,600 \neq$ & Indoor & 37 \\
\hline 10 & $113,377,000$ & Indoor & 38 \\
\hline 12 & $141,300,000 \rrbracket$ & Indoor & 38 \\
\hline 24 & $200,005,443,333 \pm$ & Indoor & 37 \\
\hline 1 & 10,543 & Outdoor & 27 \\
\hline 2 & 11,701 & Outdoor & 29 \\
\hline 3 & 34,200 & Outdoor & 31 \\
\hline 4 & 12,712 & Outdoor & 34 \\
\hline 5 & 20,667 & Outdoor & 32 \\
\hline 6 & 104,733 & Outdoor & 30 \\
\hline 7 & 114,467 & Outdoor & 30 \\
\hline 8 & 658,509 & Outdoor & 31 \\
\hline 10 & 760,733 & Outdoor & 30 \\
\hline 12 & 727,267 & Outdoor & 28 \\
\hline 24 & $66,075,516,061 €$ & Outdoor & 23 \\
\hline
\end{tabular}

$\S-1$ indicates immediately pre-pasteurization; raw milk on the farm $£ 0$ indicates immediately post-pasteurization

NR=Not recorded

$¥$ Indoor incubation was at $37^{\circ} \mathrm{C}$ during Summer

† Median $=2500 \mathrm{cfu} / \mathrm{ml}$

$\ddagger$ Median $=220,000 \mathrm{cfu} / \mathrm{ml}$

$\neq$ Median $=2,200,000 \mathrm{cfu} / \mathrm{ml}$

II Median $=3,400,000 \mathrm{cfu} / \mathrm{ml}$

\pm Median $=14,500,000 \mathrm{cfu} / \mathrm{ml}$

$€$ Median $=44,000,000 \mathrm{cfu} / \mathrm{ml}$ 
Citation: Wilson DJ, Goodell GM, Kelly T (2012) On-Farm Pasteurized Milk Fed to Dairy Calves - Association of Bacteria Counts Following Pasteurization with Season, Temperature and Time until Feeding. J Vet Sci Technol 3:124 doi:10.4172/2157-7579.1000124

year, for milk stored outdoors, any milk remaining after the first feeding following pasteurization should not be fed to calves at subsequent feedings; it should be re-pasteurized or discarded.

Further research is needed regarding health and growth effects on dairy calves of feeding milk at different levels of SPC. More precise guidelines regarding bacteria counts in post-pasteurized milk for calves can be developed when more is known about health effects of various levels of total bacteria in milk.

\section{Acknowledgements}

This research was made possible through financial support from the Agricultural Experiment Station at Utah State University. It is published as AES manuscript number 8447 . We would also like to thank the owners and staff of the cooperating dairy farms and the staff at the Dairy Authority.

\section{References}

1. Elizondo-Salazar JA, Jones CM, Heinrichs AJ (2010) Evaluation of calf milk pasteurization systems on 6 Pennsylvania dairy farms. J Dairy Sci 93: 55095513.
2. Godden SM, Fetrow JP, Feirtag JM, Green LR, Wells SJ (2005) Economic analysis of feeding pasteurized nonsaleable milk versus conventional milk replacer to dairy calves. J Am Vet Med Assoc 226: 1547-1554.

3. Jamaluddin AA, Carpenter TE, Hird DW, Thurmond MC (1996) Economics of feeding pasteurized colostrum and pasteurized waste milk to dairy calves. J Am Vet Med Assoc 209: 751-756.

4. Stabel JR, Hurd S, Calvente L, Rosenbusch RF (2004) Destruction of Mycobacterium paratuberculosis, Salmonella spp., and Mycoplasma spp. in raw milk by a commercial on-farm high-temperature, short-time pasteurizer. $J$ Dairy Sci 87:2177-2183.

5. Ruzante JM, Gardner IA, Cullor JS, Smith WL, Kirk JH, et al. (2008) Isolation of Mycobacterium avium subsp. paratuberculosis from waste milk delivered to California calf ranches. Foodborne Pathog Dis 5: 681-686.

6. Laird DT, Gambrel-Lenarz SA, Scher FM, Graham TE, Reddy R (2004) Microbiological count methods-Standard Methods for the Examination of Dairy Products. (17th ed). American Public Health Association, Washington, DC.

7. United States Public Health Service/Food and Drug Administration (2007) Pasteurized Milk Ordinance. 